\title{
User Privilege
}

National Cancer Institute

\section{Source}

National Cancer Institute. User Privilege. NCI Thesaurus. Code C42722.

The operations and access levels which are allowed to a user (e.g Create, Read, Update, Delete). 